\title{
РОЛЬ МЕДИЧНОЇ СЕСТРИ У ПОПЕРЕДЖЕННІ ВПЛИВУ МЕТЕОРОЛОГІЧНИХ ФАКТОРІВ НА СТАН ПАЦІЄНТІВ ІЗ ГІПЕРТОНІЧНОЮ ХВОРОБОЮ
}

\author{
О. П. Мялюк, М. І. Марущак, І. Я. Криницька, О. В. Руденко \\ Рівненський державний базовий медичний коледж \\ ДвНз «Тернопільський державний медичний університет \\ імені І. Я. Горбачевського МОЗ України"
}

\begin{abstract}
У статті проведено оцінку впливу природно-кліматичних та метеорологічних факторів на перебіг захворювання у пацієнтів із гіпертонічною хворобою та встановлено роль медичної сестри у профілактиці розвитку ускладнень.

Доведено, що на фоні коливання температури атмосферного повітря, динамічного зменшення кількості опадів відбувається зростання кількості стаціонарних пацієнтів кардіологічного профілю. Збільшення захворюваності та ускладнень гіпертонічної хвороби пов'язане з температурою атмосферного повітря, віку хворого і часу доби.

Запропоновано план роботи середнього медичного персоналу для профілактики гіпертонічних кризів та інших ускладнень гіпертонічної хвороби: 1) формування групи ризику серед пацієнтів зони обслуговування зі значними коливаннями артеріального тиску, особливо в нічний період; 2) розробка журналу щоденної реєстрації загальножиттєвих показників (температура тіла, артеріальний тиск, пульс); 3) навчання та контроль за правильністю реєстрації загальножиттєвих показників; 4) проведення просвітницької роботи щодо факторів ризику та профілактики розвитку гіпертонічної хвороби та ї̈ ускладнень.
\end{abstract}

\section{THE ROLE OF NURSES IN THE PREVENTION OF THE INFLUENCE OF METEOROLOGICAL FACTORS ON PATIENTS WITH HYPERTENSION}

\author{
O. P. Mialiuk, M. I. Maruschak, I. Y. Krynytska, O. V. Rudenko \\ Rivne State Basic Medical College \\ I. Horbachevsky Ternopil State Medical University
}

\begin{abstract}
This article provides an assessment of the impact of climatic and meteorological factors on the patients with hypertension and establishes the role of the nurse in the prevention of complications.

It was established that the background temperature fluctuations of air, dynamic reduction in rainfall is the growing number of inpatient cardiac patient profile. Increased incidence of hypertension and complications were associated with the temperature of the air, the patient's age and time of day.

A plan of nursing staff for the prevention of hypertensive crises and other complications of hypertension include: 1) formation of risk group among patients with significant fluctuations in blood pressure, especially at night time; 2) development of daily journal for vital parameters registration (body temperature, blood pressure, pulse); 3) training and control of accuracy of vital indicators registration; 4) educational work about risk factors and prevention of hypertension and its complications.
\end{abstract}

Вступ. Незважаючи на те, що глобальне потепління може приносити деякі місцеві переваги, такі як зменшення числа випадків смерті в місцях із помірним кліматом і зростання виробництва харчових продуктів у певних районах, загальні наслідки зміни клімату для здоров'я, найімовірніше, будуть у переважній більшості випадків негативними. Зміна клімату впливає на соціальні та пов'язані з навколишнім середовищем фактори здоров'я - чисте повітря,

(c) О. П. Мялюк, М. І. Марущак, І. Я. Криницька, О. В. Руденко, 2017 безпечну питну воду, харчові продукти. Вкрай висока температура повітря безпосередньо призводить до смерті від серцево-судинних і респіраторних захворювань, особливо серед осіб старшого віку. Так, наприклад, під час періоду сильної спеки влітку 2003 р. в Європі було зареєстровано додатково більше ніж 70000 випадків смертей [1]. До того ж, через високу температуру в повітрі підвищуються рівні озону та інших забруднювачів, що посилює серцево-судинні та респіраторні захворювання. 
Основна частина. Метою нашого дослідження було оцінити вплив природно-кліматичних та метеорологічних факторів на перебіг захворювання у пацієнтів із гіпертонічною хворобою та встановити роль медичної сестри у профілактиці розвитку ускладнень.

Проаналізовано дані з журналів реєстрації хворих, які отримували лікування в кардіологічному відділенні Тернопільської університетської лікарні за останні 3 роки (вибірка суцільна, 4247 осіб) для вивчення сезонності виникнення гіпертонічної хвороби; дані центру гідрометеорології (144 показники середньодобової температури, середньодобової відносної вологості повітря і атмосферного тиску) для дослідження впливу кліматичних факторів на захворюваність на гіпертонічну хворобу у Тернопільській області.

Для виявлення факторів ризику гіпертонічного кризу в пацієнтів із артеріальною гіпертензією проведено оцінку прихильності пацієнтів до лікування використовували тест Моріскі-Гріна, що включає 4 запитання: 1. Чи забували ви коли-небудь прий- няти препарати? 2. Чи ставитеся ви іноді неуважно до годин приймання ліків? 3. Чи пропускаєте ви приймання препаратів, якщо почуваєте себе добре? 4. Якщо ви почуваєте себе погано після приймання ліків, чи пропускаєте ви наступне приймання? Відповідь «Так» означає 0 балів, «Ні» - 1 бал. Прихильними до лікування вважали хворих, які набирали 4 бали, не прихильними - менше 3 (табл.).

У ході досліджень використані такі загально-наукові методи, як аналіз, синтез, групування та узагальнення, а також прогнозування динамічних рядів за рівнем середньої арифметичної величини.

Аналіз смертності населення Тернопільської області вказує на те, що на фоні тенденції до зниження показника загальної смертності залишається однаково висока смертність від серцево-судинних захворювань в осіб обох статей (рис. 1). Варто зазначити, що відсоток жіночої смертності від хвороб серця приблизно в 1,5 раза перевищує такі дані у чоловіків (рис. 1).

Таблиця. Оцінка прихильності пацієнтів до лікування за тестом Моріскі-Гріна

\begin{tabular}{|c|c|c|}
\hline Запитання тесту Моріскі-Гріна & Так & $\mathrm{Hi}$ \\
\hline Чи забували ви коли-небудь прийняти препарати? & 45 & 3 \\
\hline Чи ставитеся ви іноді неуважно до годин приймання ліків? & 45 & 3 \\
\hline Чи пропускаєте ви приймання препаратів, якщо почуваєте себе добре? & 18 & 30 \\
\hline Якщо ви почуваєте себе погано після приймання ліків, чи пропускаєте ви наступне приймання? & 6 & 42 \\
\hline
\end{tabular}

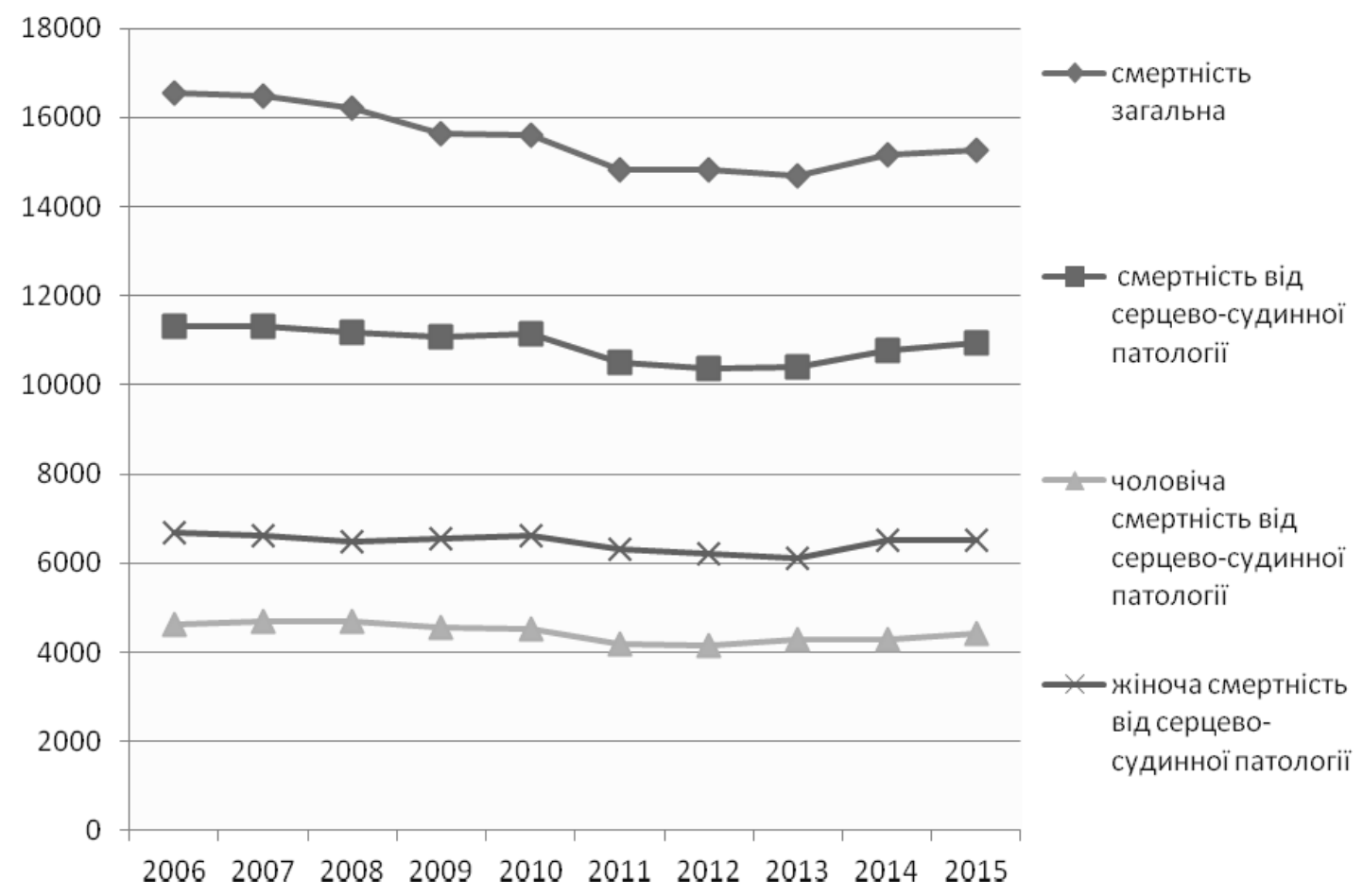

Puc. 1. Аналіз смертності населення Тернопільської області (2006-2015рр.). 
Аналіз числа пацієнтів із серцево-судинною патологією, які перебували на стаціонарному лікуванні Тернопільської університетської лікарні свідчив про зростання кількості пацієнтів кардіологічного профілю протягом останніх 10 років, при цьому отримані дані за найспекотніший місяць липень відтворювали річні тенденції (рис. 2).

Проведений статистичний прогноз вказує на динамічне зростання захворюваності на серцево-судинну патологію в Тернопільській області впродовж наступних декількох років, що потребує активного пошуку чинників розвитку даних захворювань (рис. 3). У структурі кардіологічної захворюваності протягом 10 років у чоловіків переважав інфаркт міокарда (46,4-52,1\%), у жінок - гіпертонічна хвороба (33,3-42,4\%).

За даними Світового банку, в Україні найвищі темпи скорочення населення в Європі. При цьому приблизно половини смертей віком до 75 років можна було 6 уникнути при адекватній профілактиці й лікуванні, вважають фахівці Світового банку [3].

Концепція смертності, якої можна уникнути, стосується всіх тих смертей, яким, зважаючи на сучасний рівень розвитку медичних знань та технологій, можна було б запобігти за допомогою сил охорони здоров'я через профілактику та/або лікування.

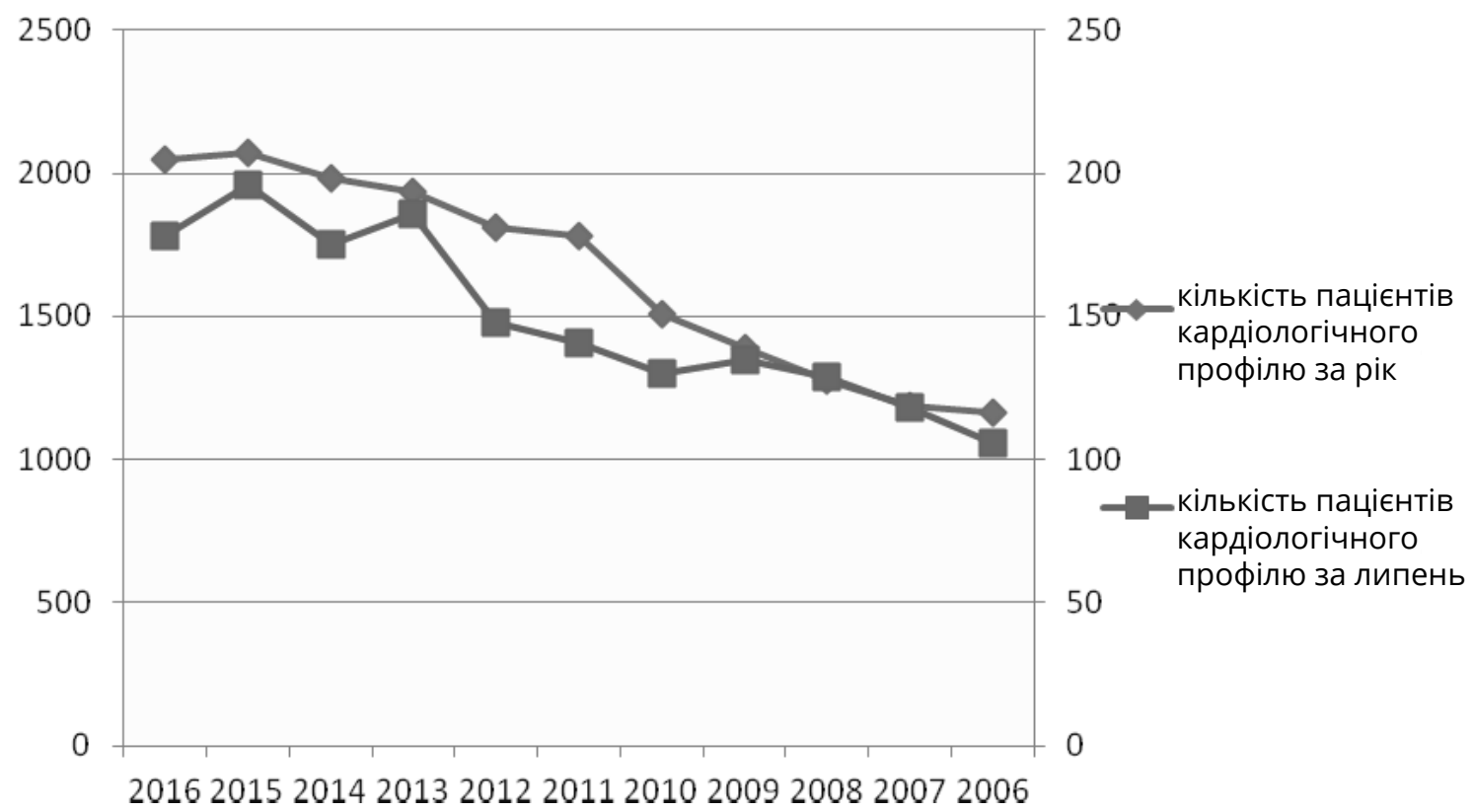

Puc. 2. Динаміка кількості пацієнтів кардіологічного профілю, які перебували на стаціонарному лікуванні Тернопільської університетської лікарні.

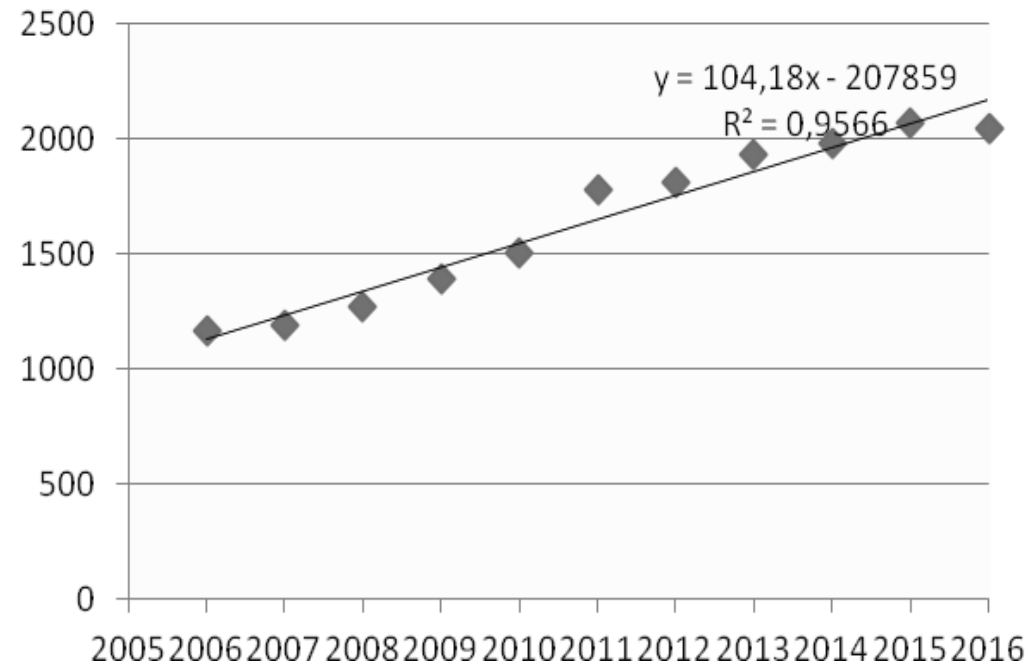

- кількістьпацієнтів кардіологічного профілю

Puc. 3. Прогнозування захворюваності на серцево-судинну патологію в Тернопільській області. 
Останніми роками швидкими темпами змінюється клімат на планеті, що найбільше впливає на серцевосудинну та нервову системи. Виявлено вплив природно-кліматичних факторів на захворюваність на гіпертонічну хворобу у Тернопільській області. Основний вплив клімату на організм людини характеризується результатом дії погоди вцілому. Комплексні методи кліматології включають погоду доби і погоду певного моменту, яка дає більш точну характеристику зміни метеорологічних факторів протягом доби. Вплив погоди і клімату на організм людини оцінюють за особливостями теплообміну людини з навколишнім середовищем, виділяючи, відповідно, комфортну (сприятливу), субкомфортну (відносно сприятливу) і несприятливу погоду [2].

Відповідно до аналізу даних журналу реєстрації хворих встановлено сезонність гіпертонічноїхвороби, яка характеризувалася зростанням числа звернень за медичною допомогою із зимово-весняними максимумами в січні-лютому і квітні-травні та у спекотні місяці липень-серпень. Цікавим також є встановлений факт, що найнижча захворюваність, проте найвища смертність, реєструвалась у вихідні дні.
Аналізуючи архівні дані щодо зміни температурної кривої, кількості опадів і кількості пацієнтів у місяці липні протягом 10 років встановлено, що на фоні коливання температури атмосферного повітря, динамічного зменшення кількості опадів відбувається зростання кількості стаціонарних пацієнтів кардіологічного профілю (рис. 4). Варто зазначити, що не було встановлено статистично значимого взаємозв'язку між даними показниками.

Наступний етап нашого дослідження - проаналізувати результати 8 записів добового моніторування артеріального тиску пацієнтів із гіпертонічною хворобою, які перебували на стаціонарному лікуванні в кардіологічному відділенні Тернопільської університетської лікарні у липні. Встановлено, що в 5 пацієнтів із гіпертонічною хворобою реєструвалися високі цифри систолічного артеріального тиску у нічний час, що корелювало $з$ температурою атмосферного повітря у нічний час і віком пацієнта. На рисунку 5 наведено взірець результатів добового моніторування артеріального тиску пацієнта.

Виявлено, що на зростанні захворюваності та ускладнень гіпертонічної хвороби позначається температура атмосферного повітря, вік хворого і нічний час.

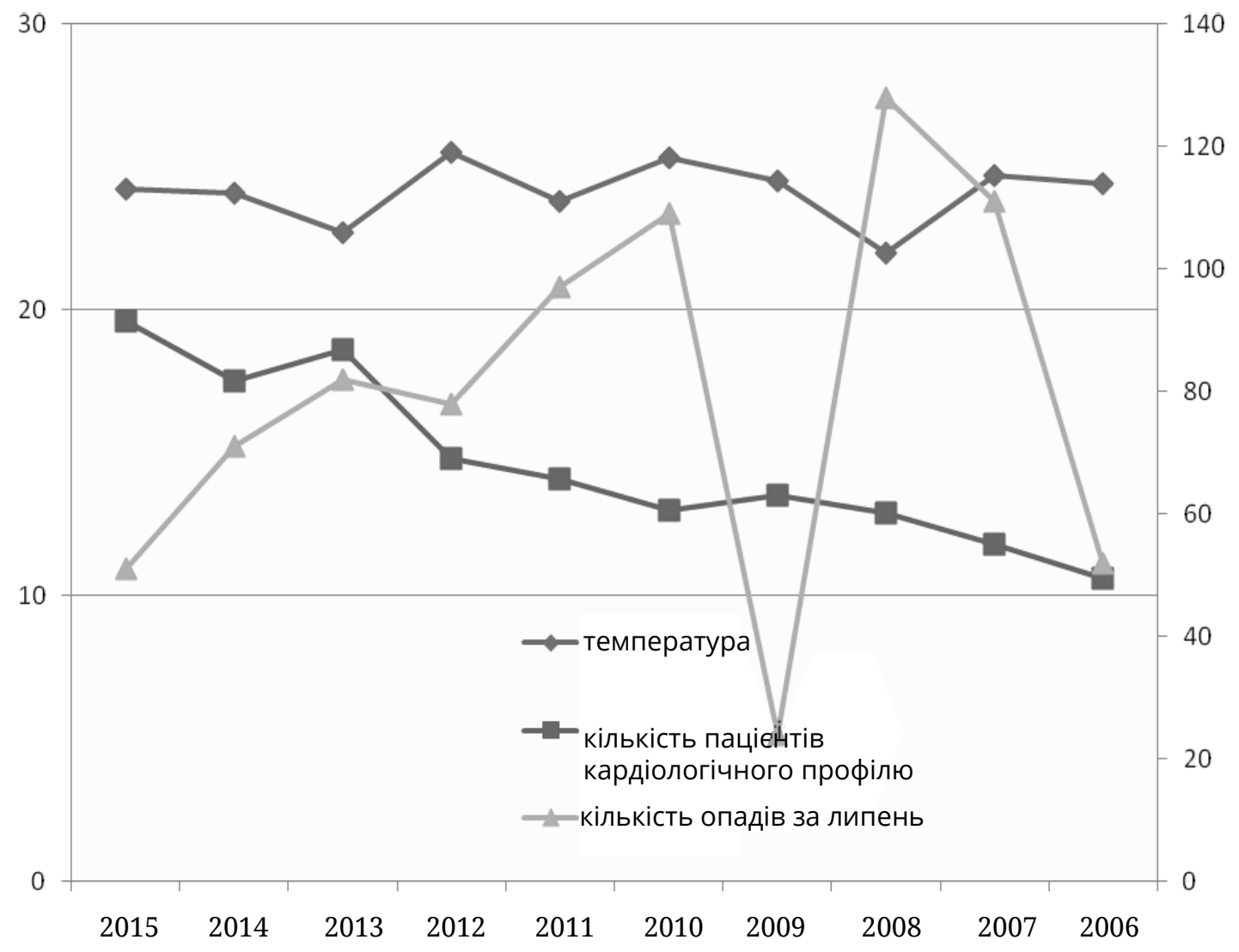

Puc. 4. Динаміка зміни температури атмосферного повітря, кількості опадів й кількості стаціонарних пацієнтів $(n=10)$ кардіологічного профілю впродовж 10 років у Тернопільській області. 
Для виявлення факторів ризику гіпертонічного кризу в пацієнтів із артеріальною гіпертензією проведено оцінку прихильності до лікування за тестом Моріскі-Гріна 48 пацієнтів (див. табл.).

Аналізуючи отримані результати, прихильними до лікування були 62,5 \%, менш прихильними - 37,5 \%. Додатково до тесту Моріскі-Гріна ми запитали у пацієнтів, як часто вони вимірюють артеріальний тиск. Встановлено, що раз на добу артеріальний тиск вимірюють лише 58,3 \%. Вважаємо, що основна роль медичної сестри полягає у проведенні просвітницької роботи щодо необхідності контролю артеріального тиску, дотриманні призначень лікаря щодо частоти приймання ліків, часового проміжку приймання медикаментів.

Далі провели анкетування 48 пацієнтів із гіпертонічною хворобою, включивши в анкету декілька запитань: 1. Чи пов'язуєте Ви підвищення артеріаль- ного тиску зі зміною погоди? 2. Чи відслідковуєте Ви погоду попередньо на наступний день? 3. Чи вмієте вимірювати артеріальний тиск? 4. Яку роль медичної сестри Ви вбачаєте у попередженні гіпертонічного кризу, пов'язаного зі змінами погоди?

Результати анкетування наведено на рисунках 6-8.

Встановлено, що 39,6 \% пацієнтів пов'язують зміну атмосферного тиску й температури повітря з підвищенням артеріального тиску, проте лише 12,5 \% 3 респондентів стежать за погодою на наступний день. Враховуючи, що раз на добу артеріальний тиск вимірюють лише 58,3 \%, ми з'ясували, чи вміють пацієнти виконувати цю маніпуляцію. Як вказують результати опитування, 20,8 \% хворих із гіпертонічною хворобою не вміють самостійно вимірювати собі артеріальний тиск, що, на нашу думку, пов'язано з низькою навчально-просвітницькою роботою саме середнього медичного персоналу.

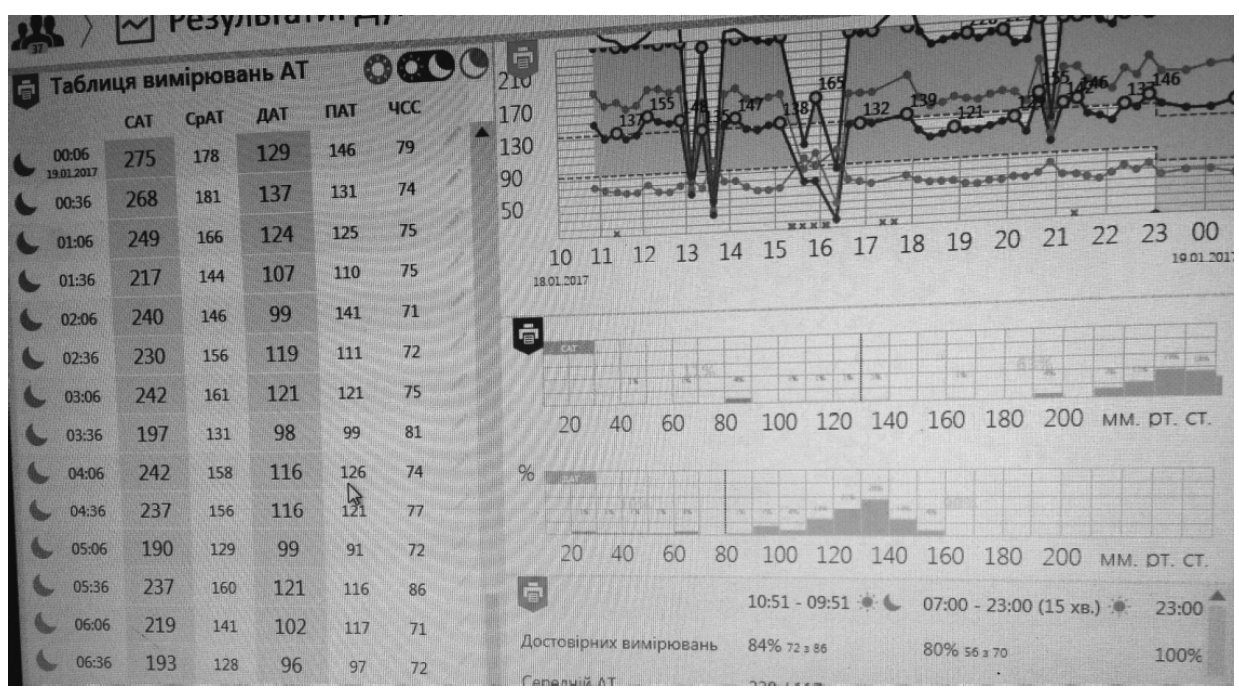

Puc. 5. Результат добового моніторування артеріального тиску пацієнта Д., віком 67 р.

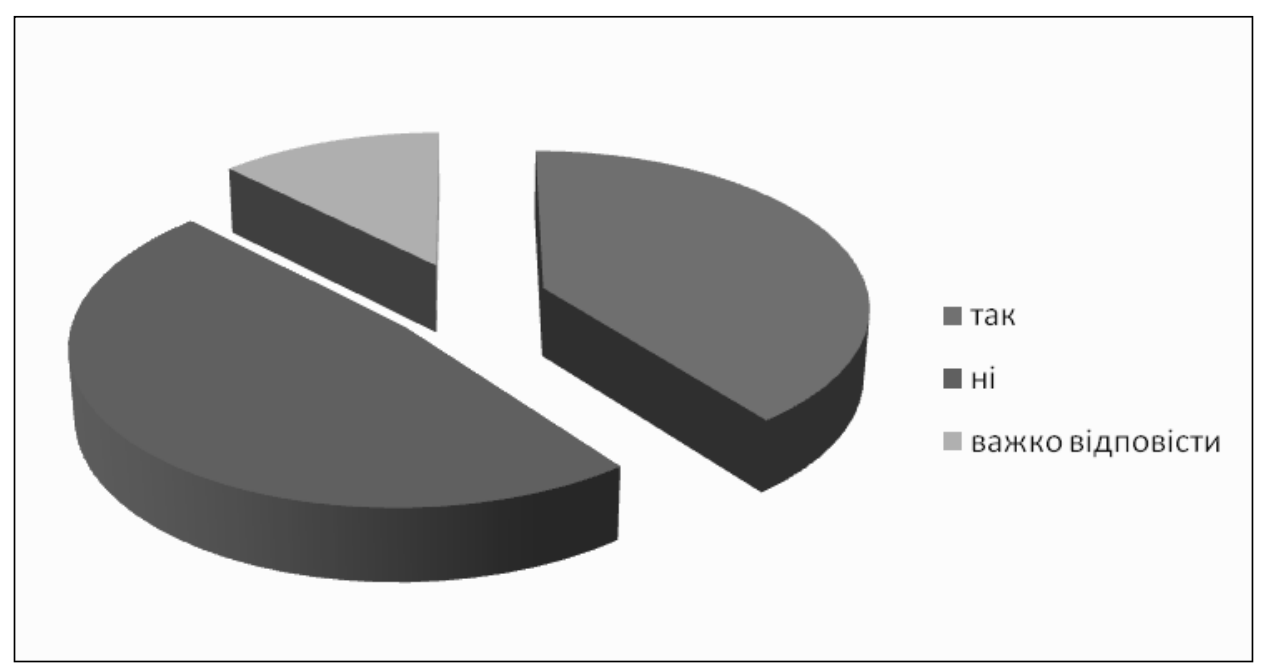

Puc. 6. Структура відповідей на запитання: Чи пов'язуєте Ви підвищення артеріального тиску зі зміною погоди? 


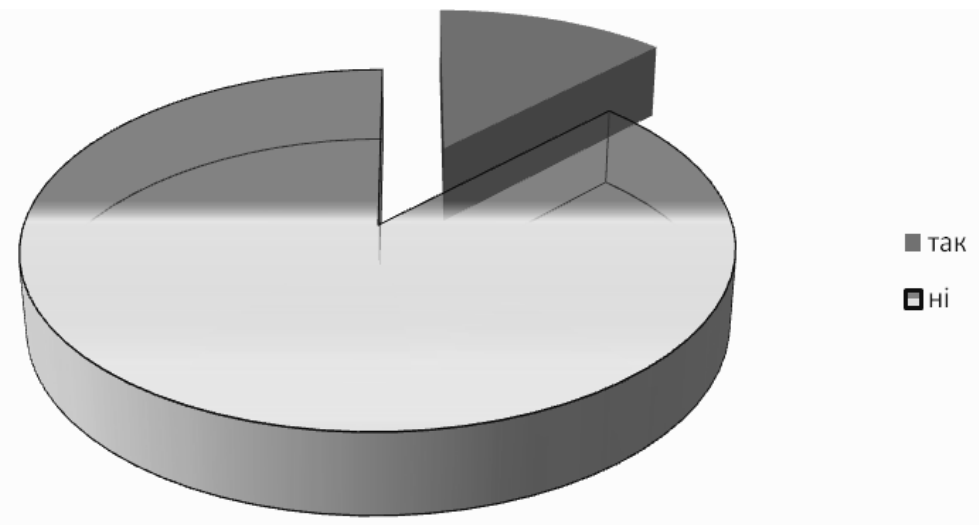

Puc. 7. Структура відповідей на запитання: Чи відслідковуєте Ви погоду попередньо на наступний день?

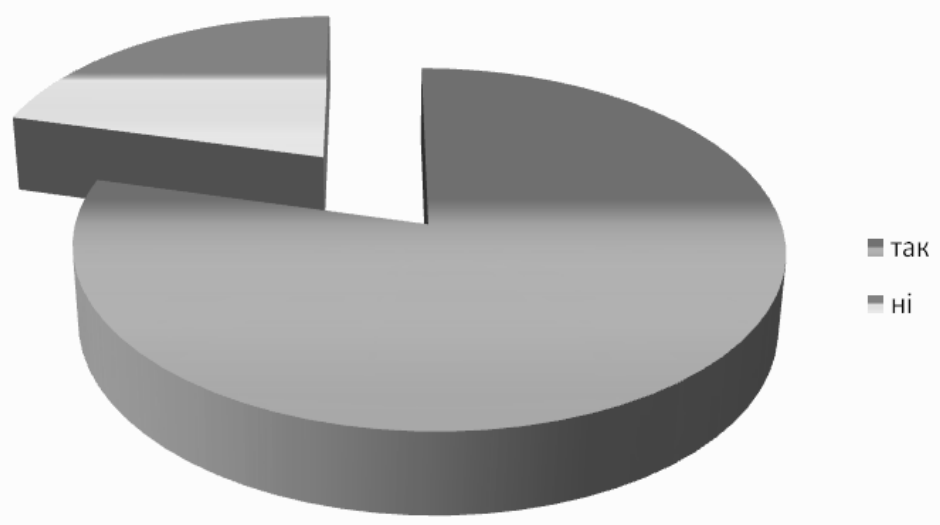

Puc. 8. Структура відповідей на запитання: Чи вмієте вимірювати артеріальний тиск?

Проведене дослідження дозволяє запропонувати план роботи медсестри для профілактики гіпертонічних кризів та інших ускладнень гіпертонічної хвороби: 1) формування групи ризику серед пацієнтів зони обслуговування щодо можливості гіпертонічного кризу; 2) розробка журналу щоденної реєстрації загальножиттєвих показників (температура тіла, артеріальний тиск, пульс); 3) контроль за правильністю реєстрації загальножиттєвих показників; 4) проведення просвітницької роботи щодо необхідності контролю артеріального тиску, оцінки погодніх умов на наступний день.

Висновки. На фоні коливання температури атмосферного повітря, динамічного зменшення кількості опадів відбувається зростання кількості стаціонарних пацієнтів кардіологічного профілю. Збільшення за- хворюваності та ускладнень гіпертонічної хвороби пов'язане з температурою атмосферного повітря, віку хворого і часу доби.

Запропоновано план роботи середнього медичного персоналу для профілактики гіпертонічних кризів та інших ускладнень гіпертонічної хвороби: 1) формування групи ризику серед пацієнтів зони обслуговування зі значними коливаннями артеріального тиску, особливо в нічний період; 2) розробка журналу щоденної реєстрації загальножиттєвих показників (температура тіла, артеріальний тиск, пульс); 3) навчання та контроль за правильністю реєстрації загальножиттєвих показників; 4) проведення просвітницької роботи щодо факторів ризику та профілактики розвитку гіпертонічної хвороби та її ускладнень.

\section{СПИСОК ЛІТЕРАТУРИ}

1. Death toll exceeded 70,000 in Europe during the summer of 2003 / J. M. Robine, S. Cheung, L. Le, S. Roy // C. R. Biol. - 2008. - Vol. 331(2). - P. 171-178.

2. Кліматолікування (аеротерапія, геліотерапія, таласотерапія, мікрокліматотерапія) [Електронний ресурс] /

В. В. Єжов, О. М. Торохтін, В. О. Поберська, С. Н. Бучинський. - Режим доступу: http://www.vafk.com/gallery/l_8.pdf

3. Кононенко О. Ю. Актуальні проблеми сталого розвитку : навч.-метод. посіб. / О. Ю. Кононенко. - К. : ДП «Прінт сервіс», 2016. - 109 с.

Отримано 05.01.17 